\title{
Małgorzata Lebda
}

ORCID: 0000-0003-4286-1450

Pedagogical University of Krakow

malgorzata.lebda@up.krakow.pl

DOI: 10.35765/pk.2019.2704.15

\section{Seeing as Action. The Methods \\ of Interpreting Visual Materials \\ on the Example of Photography}

\section{AB STRAC T}

The article asks about the power of photography. Four photographs are referred to. The author tries to describe ways of looking, analyzing and interpreting each of them. Every time, it is a subjective analysis based on individual visual competences. The concept of punctum turns out to be important, as it allows a closer look at the visual. Ultimately, the answer to the question whether in the analysis of an image we take possession of it, or is it the other way around, is solved at the level of individual reception of a particular photo.

KEY WORDS: photography, visual art, ways of seeing, punctum, study, visual competence

\section{STRESZCZENIE}

Widzenie jako dziatanie. O sposobach interpretacji materiatów wizualnych na przyktadzie fotografii

Artykuł traktuje o sile fotografii. Omówiono cztery fotografie, na których przykładzie autor próbuje opisać sposoby patrzenia, analizowania i interpretowania. Każdorazowo jest to subiektywna analiza oparta na indywidualnych kompetencjach wizualnych. Pojęcie punctum okazuje się ważne, ponieważ pozwala przyjrzeć się temu, co wizualne. Ostatecznie odpowiedź na pytanie, czy w analizie panujemy nad

Suggested citation: Lebda, M. (2019). Seeing as Action. The Methods of Interpreting Visual Materials on the Example of Photography. Perspektywy Kultury, 4(27), pp. 219-233. 
obrazem, czy obraz nad nami, jest każdorazowo rozpatrywana przy indywidualnym odbiorze konkretnego zdjęcia.

\section{SŁOWA KLUCZE: fotografia, sztuka wizualna, sposoby widzenia, punctum, studium, kompetencje wizualne}

November 2011, the interior of one of the Amsterdam galleries is filled with photographs. Printed, tangible, forming a tactile and visual installation at the same time. It is 350,000 photographs. The name of the exhibition is $24 \mathrm{Hrs}$ in Photos, the originator Erik Kessels, is a Dutch artist who has been carefully watching what is visual for over twenty-five years. ${ }^{1}$ Photographs were downloaded from the Flickr website-punctum 350,000, as so much was uploaded by portal users within twenty-four hours. Impressive and stunning. However, this should not surprise us, if we recall the data according to Nicholas Mirzoeff: within a minute, 100 hours of recordings are uploaded on YouTube, Americans take more photos in two minutes than all together throughout the nineteenth century, and a billion photos were taken in $2014 .^{2}$ This is data from a few years ago. This gesture of giving a physical form to the images uploaded on the Internet was intended to show - tangibly - the scale of the phenomenon. However, not only that. At this point, it is worth recalling the considerations of Marek Krajewski, who, speaking of the physicality of photographic images, pointed out that this aspect allows taking a new look at what is visual and how the physical image affects the recipient, what it means to them. ${ }^{3}$ Visitors walk between printed paintings and feel the physical resistance thereof. They feel subjectile as Jacques Derrida said about the materiality of an image. ${ }^{4}$ The viewer, actively looking, becomes an element of the installation, and their gesture of raising the photo and looking at it, becomes a replacement for scrolling the website on the screen. And just like

1 Manages the Kessels Kramer advertising agency, famous for unusual (often provocative) solutions: http://www.kesselskramer.com/ (access: 20.12.2018)

2 Cf. N. Mirzoeff, Jak zobaczyć świat, transl. Ł. Zaręba, Kraków-Warszawa 2016, p. 20.

3 Cf. "Noticing objects in photos means that they can be analyzed in a different way than the usual practice. At the center, first of all there is a question what the photos mean to individuals, not what they depict and how they depict it. Its significance is primarily due to the fact that by asking it we place photography in the context of other social practices, and a photo within the material context of our life. Thus, answering them not only avoids the unnecessary exoticization of what is visual, because it roots them in a world of common experience, but also allows using the tools created for the purposes of analyzing other material representations as a means of studying photographs," M. Krajewski, Fotografie jako przedmioty, https://www.academia. edu/1978609/_Fotografie_jako_przedmioty (access: 20.12.2018).

4 Cf. J. Derrida, P. Theverin, Antonin Artaud. Dessins et portraits, Paris 1986, p. 53. 
there, also inside the building it is impossible to see all the photographs. The act of seeing, sight — or as Mirzoeff would define it - action, ${ }^{5}$ has a tangible importance here. This visual performance prompts reflection on how we look at the photographic image. Does it still make sense to ask questions as W.J.T. Mitchell "what do paintings want?" Among the answers formulated by the researcher, the slightly metaphorical one (based on The Wife of Bath's Tale by Chaucer) telling about the desire to control the image over the viewer seems to be significant. ${ }^{7}$ Images want it, as well as maistrye. ${ }^{8}$ A space opens up here to think about how we treat images, do we let them control ourselves, who ultimately controls whom: do we control the image or the image controls us? Hence the following questions about: life of images, protest of images, subversiveness of what is visual and our place - of the viewers - in all this. To illustrate such a broad context, subjectively selected visual material will be used, in which the Barthesian punctum is visible, i.e. something that does not allow one to be indifferent to a particular photograph. And here, at the stage of choosing a photograph, it turns out that it was made under the influence of a gesture that could not be defined otherwise than by Barthesian term punctum - a gesture of mastering the imagination of the viewer through the image. At this point, the image is already in control of the viewer. This punctum, which is like a prick, a wound, is "the case that in this photo is aimed at me (but it also strikes, oppresses me)." ${ }^{9}$ Below are three approaches at four different photographs, each of which has a "sharp point" that catches the eye. Where will the reader of this text find punctum in these images? Is the realization of punctum the first step to possessing the image or being possessed by it?

\section{The first sight}

Full Moon, An Unidentified Object in the Sky, Taking a Selfie. These are the terms most often mentioned by students when asked about what they see in the photograph of John Stanmeyer. They have enough time for analysis so that - after these first clues-doubts arise. There are People in the

5 Cf. N. Mirzoeff, Jak zobaczyć świat, op. cit., p. 6.

6 W.J.T. Mitchell, Czego chca obrazy, in: Antropologia kultury wizualnej, eds. I. Kurz, O. Kwiatkowska, Ł. Zaręba, Warszawa 2012, pp. 185-189.

7 Ibidem, p. 188.

8 “... a complex term of Middle English, comprised within the rule, resulting from law or consent, and authority based on superiority or cunningness," ibidem.

9 R. Barthes, Światto obrazu, Warszawa 1996, p. 161. 
Landscape, a fragment of the poem by Tomas Tranströmer is recalled. ${ }^{10}$ There are many disturbing things here: night, sea, male silhouettes, tension and anticipation. In front of us there is the shoot of an American photographer who was awarded in the 75th edition of World Press Photo (2013). The photo shows African immigrants on the Djibouti coast who is trying to connect to a cheaper mobile network from neighboring Somalia. It is the only way to talk to their families.

Photo 1

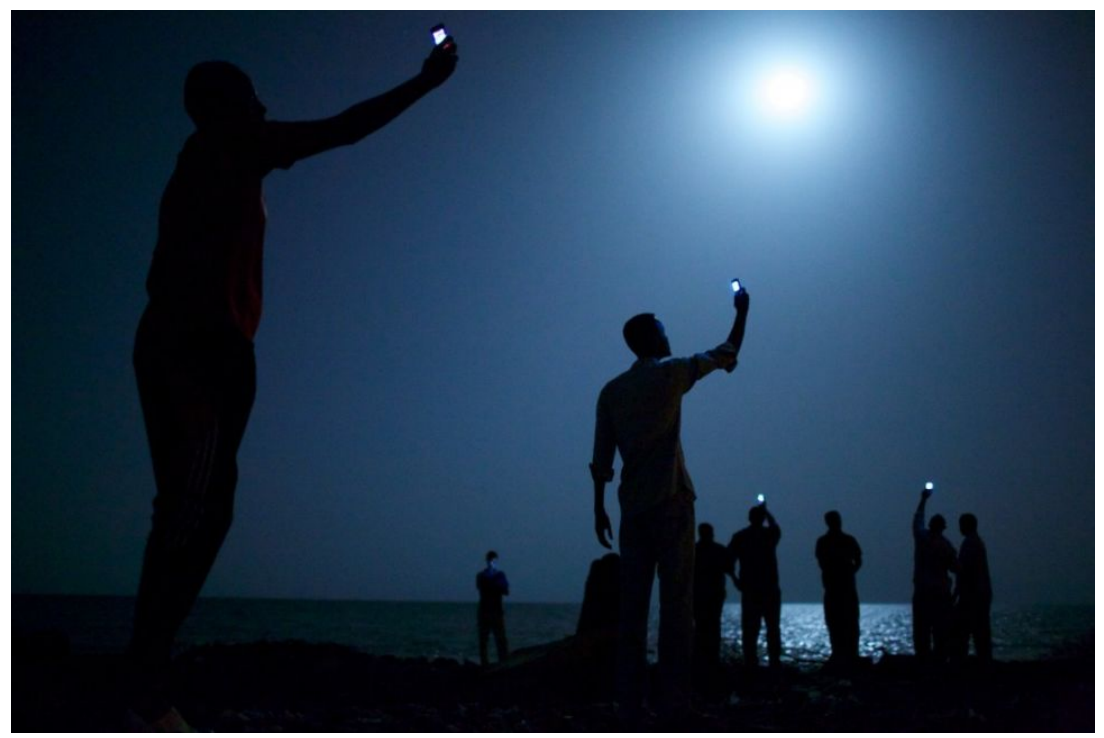

Source: https://www.worldpressphoto.org/collection/photo/2014/contemporary-issues/ john-stanmeyer.

This photograph, deprived of context, reveals as much about itself as we already know visually. Here Stanmeyer provokes to ask a specific question: about the strength of this image, its potential power of change, reconfiguration in thinking about-for example — the refugee crisis. Of course, this somewhat poetic and, in fact, ambiguous, metaphorical frame does not seem to be the best choice if we want to talk about a "Protest of Images." But that is why it is worth taking a closer look at it, because it raises questions, it does not play with the brutality of the performance. ${ }^{11}$ It is not

10 T. Tranströmer, Wiersze i proza 1954-2004, transl. M. Wasilewska-Chmura, L. Neuger, Kraków 2017.

11 How else would this interpretation look if the subject of reflection was the photograph of Burhan Ozbilici depicting the assassin of the Russian ambassador in the gallery building in Ankara? 
a "photo-shock" 12 as Roland Barthes wrote about the photographs exhibited in the Gallery D'Orsay. There is an ambiguity in which tension and anxiety can be noticed. The author of the photographs managedonce again, as if to confirm Barthes's diagnoses - to cause horror without literality, because, as the French semiologist argues: "Literal photography introduces the horror scandal, not the horror itself." ${ }^{13}$ The people photographed in the Gulf of Aden create a metaphorical image that leaves the viewer with interpretive space. It is an image that even without context seems to work through its poetry and something close to it seems to be the concept of Gottfried Boehm namely "iconic density" which

... is (from the point of view of verbal language) what is the emptiest in the image: a non-figure, i.e. A simultaneous form of relationship between the figures, between the figure and the composition, between the figure and the color scheme, etc. In the uncertainty of the contrast between the boundaries is comprised both irreplaceable sensuality and this "logic" of correspondence, which form the phenomenal datum of a specific image. We are dealing here with a paradox that indeterminacy is precisely what is visibly the most concentrated, in which the vividness of an image becomes most distinctly itself, i.e. a phenomenon. ${ }^{14}$

The first contact with this image was undoubtedly associated with thinking about its intensity. What it wants from a viewer? Mindfulness. This is not a simple photojournalistic message, it is an image built on poetic tensions, in which the most important seems: an understatement, metaphoricity, a symbol. There is also that: a non-place. ${ }^{15}$ We are dealing here with a place that is not anchored in history and memory, a transitional, transit, anonymous place, which is only a point of transition, a short stop in an uncertain journey. This is a non-place where the actors of this visual scene are located, it additionally builds a feeling of uncertainty, because if in this picture we are not even anchored by space (it is nameless, raw, inaccessible), it makes the visual representation secret. It is worth looking at it through the neuroesthetic prism of "Eight laws of artistic experience," formulated by Vilayanur S. Ramachandran and William Hirstein, who propose an analysis of visual materials based on their principles. ${ }^{16}$ According

12 Cf. R. Barthes, Mitologie, Warszawa 2008, p. 139-141.

13 Ibidem, p. 141.

14 G. Boehm, O obrazach i widzeniu, Kraków 2014, p. 164.

15 Cf. M. Augé, Nie-Miejsca: wprowadzenie do antropologii nadnowoczesności: fragment, "Teksty Drugie: teoria literatury, krytyka, interpretacja,” No. 4 (112), 2008, pp. 127-140.

16 These include: (1) the principle of peak shift (2) the principle of isolation of a single visual indicator, (3) the principle of perceptual grouping, (4) the principle of contrast extraction, (5) the 
to researchers, if a visual work meets any of these principles, then-simplifying - it guarantees that the recipient shall experience it more deeply, remember it for long. And so, it is in this case, the photo mentioned clearly refers to several of the rules indicated above. It uses the most the "principle of using visual metaphors," which is based on the belief that "... an object discovered with effort brings more pleasure than the one that is just given. The reason for this is unclear, but a mechanism of a similar nature convinces that just struggling with difficulties only is profitable." ${ }^{17}$ This photography requires mindfulness, it is a kind of visual jigsaw, which, however, without context seems to be only a well-constructed frame. In context, however, this image works quite differently, suddenly all the elements begin to mean something: the light of the phone becomes a metaphor of contact and longing, the moonlight reflected on the surface of the water turns into a sinister void of the night. Along with the exposed context, this image begins to belong to politics, becomes an image in action, then-to use Mitchell's term-the catalyst image. ${ }^{18}$ And punctum: a man in the bottom right corner who seems to be staring at the water surface.

\section{The second sight}

Multiplication. Hands raised high. From the blurred background, we can bring out the outlines of a woman with the most mysterious smile in the world. This is clearer if we focus our eyes on the devices that are here to

principle of challenging perception, (6) the principle of avoiding atypical points of view, (7) the principle of using visual metaphors, (8) the principle of usability and attractiveness of symmetry. Cf. V.S. Ramachandran, W. Hirstein, Nauka wobec zagadnienia sztuki, in: Studia z kognitywistyki filozofii umystu, Poznań 2006, Zysk i S-ka, pp. 361-362.

17 Ibidem, p. 355.

18 "Images have power, but it is not a physical force based on a constant cause-effect relationship with people or things. A person or a thing must be sensitive to the power of the image in some way. If we were to rely on the physico-chemical model of strength, to understand it as 'the ability to introduce change', I would propose a meta-image in the form of a catalyst. In chemistry, the name refers to a substance that appears to facilitate the reaction, although it remains unchanged. In other words: as a factor in catalysis, an image can accelerate something that is already happening, but cannot itself be the cause of what is happening. Like the catalyst, the image is indifferent, but its presence can accelerate the process, which would take place much more slowly. It is sometimes said that reporters' photos revealing the horror of the Vietnam War brought it to an end. I deeply doubt the truth of this statement. Photographs were effective, helped to mobilize political passion and resistance. However, the photos alone did not cause anything. They served as catalysts for things that were already happening." Cf. W.J.T. Mitchell, Kwestionariusz: Protest obrazów, transl. P. Mościcki, "Widok. Teorie i praktyki kultury wizualnej," 2017, No. 17, http://pismowidok.org/index.php/one/article/view/515/973 (access: 20.12.2018). 
stop the image, visually repeat what is already visually stopped. Martin Parr, the author of the above-mentioned photography, has been interested for years in how the individual functions in society, his works show - often zoomed - the faces of the nouveau riche social layer.

Photo 2

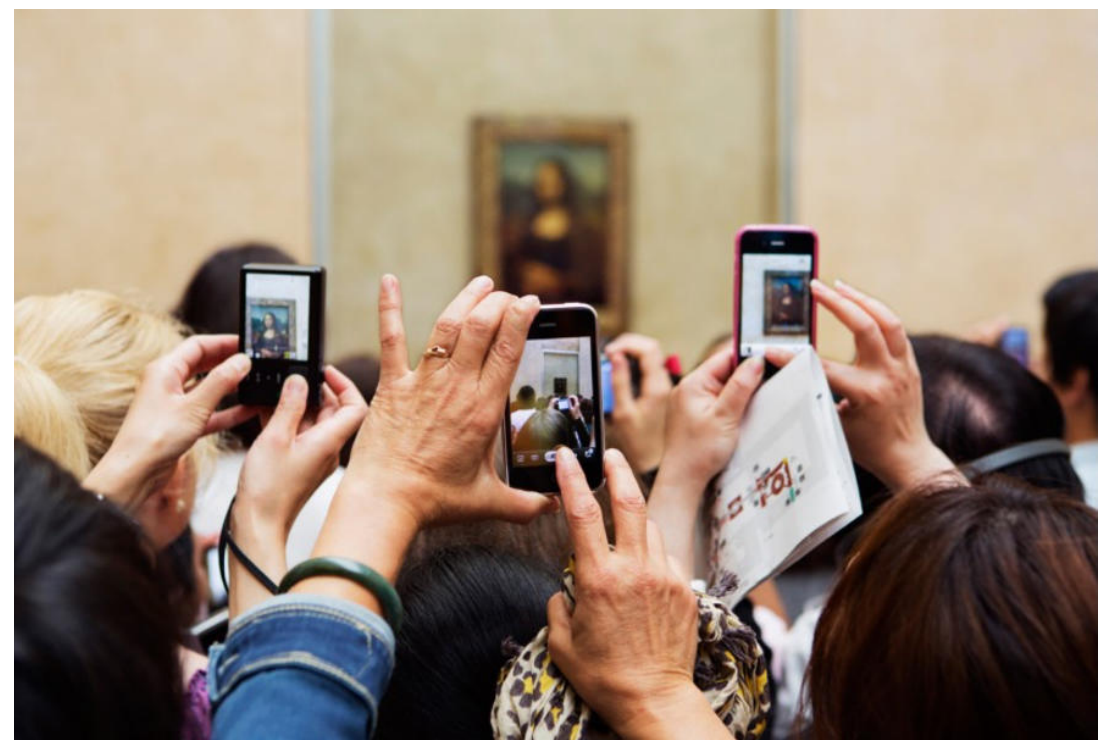

Source: https://pro.magnumphotos.com/CS.aspx?VP3 =SearchResult\&VBID $=2 \mathrm{~K} 1 \mathrm{HZO}$ 4R2ORIQ2.

Almost every time, it is a critical, ironic look. Let us look again at Mona Lisa, who, like Leonardo da Vinci's other work, has become "an element of tourist marketing." ${ }^{19}$ Parr makes an interesting act here by blurring the famous portrait. His lens is focused on the behavior of tourists-hands in action. There is a pop-culture multiplication of the image, something that Maria Poprzędzka discussed in relation to the most famous Louvre work, and which is associated with overrepresentation of this image in mass culture. "This unfortunate picture is lost to culture" she said. It has already been completely annihilated by all these pop-cultural uses and abuses. It is actually gone." ${ }^{20}$ Significantly, photography shows how man creates new simulacra, introduces phantom images into reality, characters that will resemble the original image, but will never be the same. John Urry said that

19 M. Poprzęcka, Patrz!, Gdańsk-Warszawa 2015, p. 111.

20 Zob. Mona Lisa już nie istnieje, Polskie Radio, Dwójka, https://www.polskieradio.pl/8/402/ Artykul/479338,Mona-Lisa-juz-nie-istnieje (access: 20.12.2018). 
"A tourist's look includes signs, and tourism is about collecting signs." 21 The photographer himself also takes part in this collection of signs, by photographing people who take photographs. The gesture of directing the camera's focus to the devices makes the original image become a blurred image, it exists for us in multiplied views, similar but yet only a copy. This is an image about a subversive message, which, according to Grzegorz Dziamski,

consists in imitating, identifying with the object of criticism, and then gently shifting meanings. This moment of shifting meanings is not always visible to the viewer. This is not a straightforward, direct criticism, but a criticism full of ambiguity, referring to a secret agreement with the viewer, who must follow the author's thought, and very often construct the critical meaning of the work. ${ }^{22}$

The viewer's sight is separated here from the original image through the image recording devices, they see and freeze the image as it will be visible to the recipient. It seems that seeing as action is limited here. The photographer joins this subversive game. He is standing further from the original than the photographers, standing tightly in front of him. Taking a photograph of people taking photographs, he emphasizes the subversive nature of this moment. And punctum: a ring on the palm of the left hand of one of the photographed women.

\section{The third sight}

Vivian. Whoever has seen at least one of Vivian Maier's photographic selfportraits will easily recognize the artist in the reproduction here. The story of her perception of the world is unusual, it turns out that she did not develop her photos at all, which happened upon her death. It is possible that because of the awareness of the fact that the frames deliberately set by her will remain out of her sight, maybe that's why she photographed her reflection somewhat obsessively.

21 J. Urry, Spojrzenie turysty, Warszawa 2007, p. 17.

22 G. Dziamski in a conversation: Wartościq sztuki krytycznej jest to, że wywotuje dyskusje i prowokuje do rozmów o wartościach, "Gazeta Malarzy i Poetów," No. 2-3, 2001, http://witryna.czasopism.pl/gazeta/artykul.php?id_artykulu=56 (access: 20.12.2018). 


\section{Photo 3}

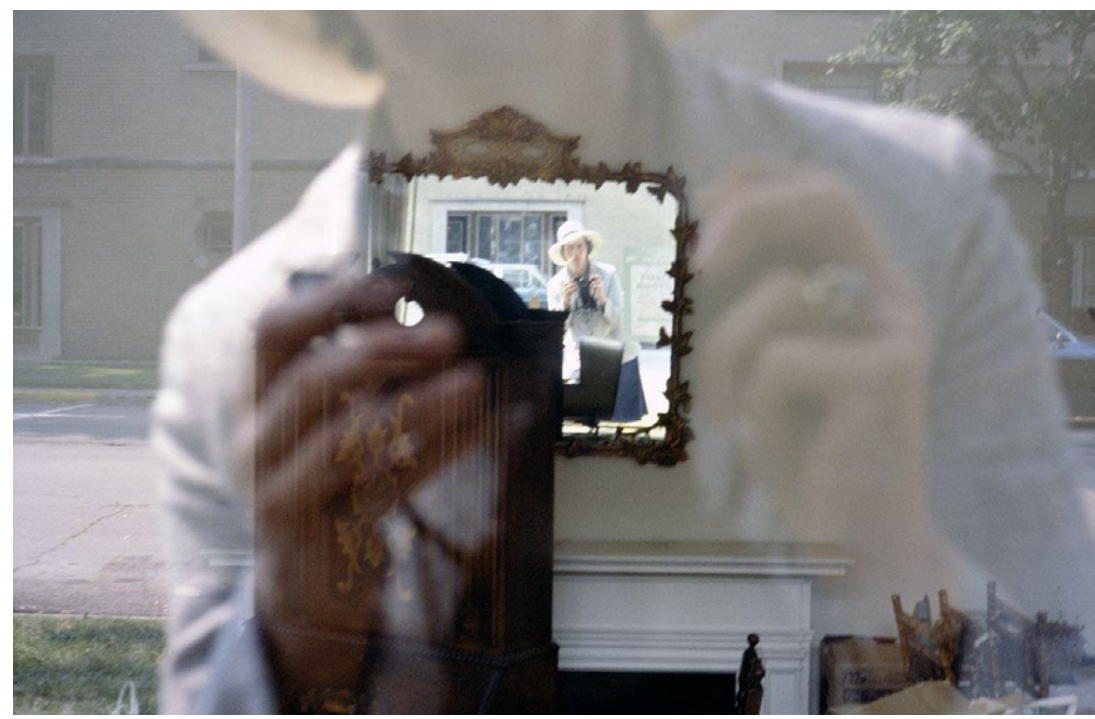

Source: http://cdn.vivianmaier.com/wp-content/uploads/2013/10/VM1979K05841-07MC.jpg

Capturing oneself in reflections (mirrors, windows, puddles) is-as it seems - a substitute for physical photography, a preview of what will be reproduced on photosensitive material. And once again we are dealing with reproduction. This time, the self-portrait has two dimensions: a blurred outline stuck on the glass shop window and a clearer figure on which the focus is reflected in the mirror hung inside the room. This complicated frame required the photographer to be mindful, one would like to say as John Berger that conscious gazing takes place here, which is an act of choice and more:

We never look at just one thing. We always look at the relationship between things and ourselves. Our seeing is characterized by constant activity, constant mobility, constant inclusion in the circle of things around it, which it covers, the constitution of what is our reality at this moment. ${ }^{23}$

And this shot, this self-portrait, discusses the classic understanding of this genre, in which, as Philippe Lejeune believed, the self-presentation of man is important, not the world. ${ }^{24}$ The obsessive gesture of photographing

23 J. Berger, Sposoby widzenia, transl. M. Bryl, Warszawa 2008, pp. 8-9.

24 Cf. "So I see the self-portrait as a special situation, a little ambiguous, which allows a violent disruption inside a very specific genre, which is a portrait, by some spark that can only shine in the mind of the beholder. This allows to see the essence of art in a dizzying look: being 
seems to be the artist's way of "stopping life," although paradoxically the thought of photography, the act of immortalizing a moment from here and now, evokes the concepts of time, transience, and death. We remember the photo by Alexander Gardner The portrait of Lewis Payne recalled by Roland Barthes, dated 1865, which shows a young man waiting to be hanged (as punishment for an attempted murder of the US Secretary of State W.H. Seward). It is here that the French semiologist diagnoses: "The photo tells me about death in the future." ${ }^{25}$ And to complete, the necessary fragment from André Bazin: "Death is only a victory of time. To capture the physical appearance of a human being artificially - that is, tear it away from the river of transience and load it onto the ship of life." ${ }^{26}$ Maier's gesture was, in fact, incomplete, there was no physical realization, it remained implicit, never seen by her. Photographing in her case ended with choosing a frame and pressing the shutter button. The life story of the American artist ends in insanity and loneliness. Looking at her legacy, it seems that Susan Sontag made the diagnosis associated with her:

The increasingly complex sense of reality creates its own compensatory elation and simplification, of which taking photos is particularly addictive. It is as if photographers, responding to a fading sense of reality, were looking for a transfusion - a journey for new experiences, refreshing past sensations. Their ubiquitous actions mean the most radical and safest version of mobility. The desire for new sensations translates into the desire to take photos: experience seeking a form resistant to the crisis. ${ }^{27}$

From the film Looking for Vivian Maier we learn that she was: "full of paradoxes," and defined as: "bold," "mysterious," "eccentric," "secretive," "crazy," "introverted," "seemed unusual." Through the camera, she reduced the distance, and appeared in the role of the one who is looking, and this was associated with a sense of control over the situation, imposing certain rules. This is a gesture of taming and appropriating reality. The film referred to herein uses fragments of a video recording in which she asks her pupils (we know she worked as a nanny) a question: "Say how can one live forever?" She found the way herself. Her vision was an action or counteraction against the passing time. To live forever is-however romantic

a self-presentation of a man (not a representation of the world), the self-portrait becomes an allegory of art itself," B. Czubak, Egocentryczne, niemoralne, przestarzałe. Wspótczesne wizerunki artystów, Warszawa 2005, p. 3.

25 R. Barthes, Światto obrazu, op. cit., p. 161.

26 A. Bazin, Ontologia obrazu fotograficznego, in: Antropologia kultury wizualnej, op. cit., p. 224.

27 S. Sontag, O fotografii, transl. S. Magala, Kraków 2009, p. 171. 
it sounds - to be in a photograph. I punctum: arrangement of the artist's hand is visible in both reflection and in the mirror.

\section{The fourth sight}

... I dug out, from under the ground / from a pile of other photos, hell: salgado / and this hell brought gold to me in ultraviolet and infrared / in the Sierra Pelada and in photographs // my eye went crazy, it took more photos of salgado photographs / photos along and across photos around / photos more and more new ones appeared. ${ }^{28}$

This is what Agnieszka Mirahina wrote in the poem Polaroid's Curse [Przekleństwo polaroida]. The poet's sight works in this poem, expressing in speech the powerful power of photography by Sebastião Salgado. These almost apocalyptic shots depicting hundreds of people in close formation. Human anthill. The photographer arrived at the gold mine in Serra Pelada. It was the place where gold was found in 1979, the nugget weighed 6 grams and it was enough to unleash a gold rush. Within a few weeks thousands of people came there who worked in slave conditions, using only their own muscles. Over time, this place became a hell on earth, in which even murders occurred due to misunderstandings. Salgado came there as a viewer, unaffected by the gold rush, and carefully photographed the Cassandrian frames. Looking at the image referred to here, one gets the impression that human work is perfectly arranged there and follows the rhythm imposed from above. Human bodies merge into one working mass. Black and white also average the performance, in black and white the contours of the bodies can be seen more clearly, the picture gains dynamics.

What does this image do with the viewer? Does it hypnotize them? Does it keep them close? Does it possess them? It seems, apparently, all of it. Here-as it often happens with difficult photos - appears a thought that (referring to Anka Herbut's description), 29 “one does not know how to look." One can try to separate the aesthetic values of photography from the content, but this is a difficult procedure, in this case perhaps impossible. The frame is built on tensions in shades, although only using black and white, between these color poles, the photographer managed to bring out the color dynamics: from black through gradations of grey to white, extracted with light. Tensions are brought about by the subject immortalized

28 A. Mirahina, Radiowidmo, Wrocław 2009, p. 23.

29 A. Herbut, Nie wiadomo jak patrzeć, "Dwutygodnik," https://www.dwutygodnik.com/ artykul/5642-nie-wiadomo-jak-patrzec.html (access: 20.12.2018). 
here, human bodies in a hurry, as if in a fever, temporary ladders, soil falling and falling under the feet. Madness, insanity that can also affect the viewer:

... I already had a whole armful of films / I folded them into trumpets and stuffed them in the corners // and as soon as I was managed to insert the film / ready prints appeared! // and anything I looked at changed into a photo / which faded with the dawn, ${ }^{30}$

Mirahina continues in her poem. And punctum: a man in the center, as if frozen on a ladder.

Photo 4

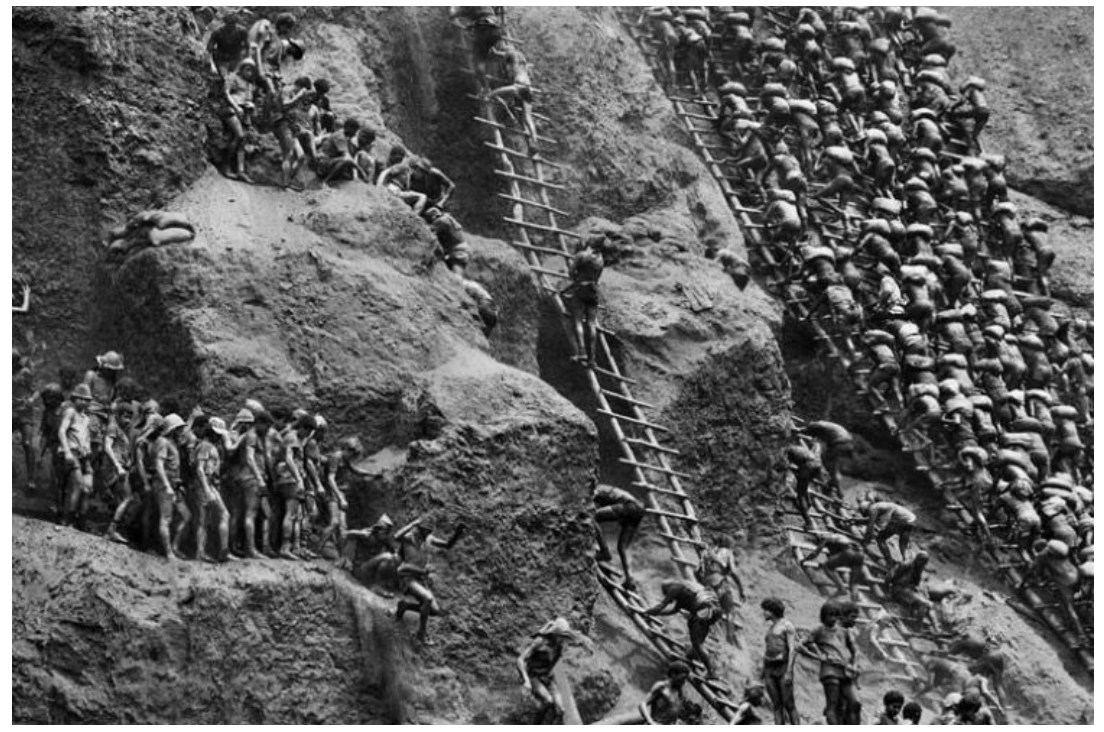

Source: https://i2.wp.com/huxleyparlour.com/app/uploads/2018/03/BHC0513.jpg?.w = $760 \& s s l=1$.

What does this image do with the viewer? Does it hypnotize them? Does it keep them close? Does it possess them? It seems, apparently, all of it. Here-as it often happens with difficult photos — appears a thought that (referring to Anka Herbut's description), ${ }^{31}$ “one does not know how to look." One can try to separate the aesthetic values of photography from

30 A. Mirahina, Radiowidmo, op. cit.

31 A. Herbut, Nie wiadomo jak patrzeć, "Dwutygodnik," https://www.dwutygodnik.com/ artykul/5642-nie-wiadomo-jak-patrzec.html (access: 20.12.2018). 
the content, but this is a difficult procedure, in this case perhaps impossible. The frame is built on tensions in shades, although only using black and white, between these color poles, the photographer managed to bring out the color dynamics: from black through gradations of grey to white, extracted with light. Tensions are brought about by the subject immortalized here, human bodies in a hurry, as if in a fever, temporary ladders, soil falling and falling under the feet. Madness, insanity that can also affect the viewer:

... I already had a whole armful of films / I folded them into trumpets and stuffed them in the corners // and as soon as I was managed to insert the film / ready prints appeared! // and anything I looked at changed into a photo / which faded with the dawn, ${ }^{32}$

Mirahina continues in her poem. And punctum: a man in the center, as if frozen on a ladder.

\section{Possession}

The images cited above differ a lot, from the technical details, through themes, ending — maybe somewhat metaphorically — with the strength of the impact. These few looks showed that each time the approach to the image and our being with it, takes place depending on our approach to the given photograph. We are talking here about cultural and visual competences that dictate how we treat what we see. The images seem to take possession of us, if the viewer is ready to open up to the punctum of visual communication. The life of images, the protest of images, are realized in the way we use, duplicate, recall, process them. Seeing as an action is possible, but only when we consciously want to let it happen. Finally, a question-have you ever photographed your own feet? Leipzig 2014, Erik Kessels shows the installation "My Feet." These are images of over 2.5 thousand feet photographed by Internet users. What photographs are uploaded into the virtual space tells us how we see and what is important to us. The projects done by Kessel track what is strange, not obvious, something that seems to be marginal, but still has its visual representation. Let us take a look at what we photograph ourselves, why we photograph it and what has the image in the frame has to do with it? And when it comes to the possession of the viewer by an image, it seems that this power is given away /or not, based on negotiations between the viewer and the image.

32 A. Mirahina, Radiowidmo, op. cit. 
Each time it is a process, arranging with a visual representation, surrendering to it, maybe even like the poet referred to, dreaming:

... and the photos were like silent vampires like an old / old joke // finally I was exhausted, the film broke off // time stood still and nothing changed // kilometers fly past, film out of the windows, the projector noise increases / I still can't sleep and close my eyes to burst and fall into butterflies / like confetti. ${ }^{33}$

Bibliography

Augé M., Nie-Miejsca: wprowadzenie do antropologii nadnowoczesności: fragment, "Teksty Drugie: teoria literatury, krytyka, interpretacja," Iss. 4 (112), 2008.

Barthes R., Mitologie, Warszawa 2008.

Barthes R., Światto obrazu, Warszawa 1996.

Bazin A., Ontologia obrazu fotograficznego, in: Antropologia kultury wizualnej, eds. I. Kurz, O. Kwiatkowska, Ł. Zaręba, Warszawa 2012.

Berger J., Sposoby widzenia, transl. M. Bryl, Warszawa 2008.

Boehm G., O obrazach i widzeniu, Kraków 2014.

Czubak B., Egocentryczne, niemoralne, przestarzałe. Wspótczesne wizerunki artystów, Warszawa 2005.

Derrida J., Theverin P., Antonin Artaud. Dessins et portraits, Paris 1986.

Mirahina A., Radiowidmo, Wrocław 2009.

Mirzoeff N., Jak zobaczyć świat, transl. Ł. Zaręba, Kraków-Warszawa 2016.

Mitchell W.J.T., Czego chca obrazy, in: Antropologia kultury wizualnej, eds. I. Kurz, O. Kwiatkowska, Ł. Zaręba, Warszawa 2012.

Poprzęcka M., Patrz!, Gdańsk-Warszawa 2015.

Ramachandran V. S., Hirstein W., Nauka wobec zagadnienia sztuki, in: Studia z kognitywistyki filozofii umystu, Poznań 2006.

Sontag S., O fotografii, transl. S. Magala, Kraków 2009.

Tranströmer T., Wiersze i proza 1954-2004, transl. M. Wasilewska-Chmura, L. Neuger, Kraków 2017.

Urry J., Spojrzenie turysty, Warszawa 2007.

Netography

Herbut A., Nie wiadomo jak patrzeć, "Dwutygodnik," https://www.dwutygodnik.com/artykul/5642-nie-wiadomo-jak-patrzec.html (access: 20.12.2018).

33 Ibidem. 
Interview with Grzegorz Dziamski, Wartościa sztuki krytycznej jest to, że wywotuje dyskusje $i$ prowokuje do rozmów o wartościach, "Gazeta Malarzy i Poetów”, Iss. 2-3, 2001, http://witryna.czasopism.pl/gazeta/artykul. php?id_artykulu=56 (access: 20.12 .2018$)$.

Krajewski M., Fotografie jako przedmioty, https://www.academia.edu/1978609/ Fotografie_jako_przedmioty (access: 20.12.2018).

Mitchell W.J.T., Kwestionariusz: Protest obrazów, transl. P. Mościcki, "Widok. Teorie i praktyki kultury wizualnej”, 2017, Iss. 17, http://pismowidok.org/ index.php/one/article/view/515/973 (access: 20.12.2018).

Mona Lisa już nie istnieje, Polskie Radio, Dwójka, https://www.polskieradio. pl/8/402/Artykul/479338,Mona-Lisa-juz-nie-istnieje (access: 20.12.2018).

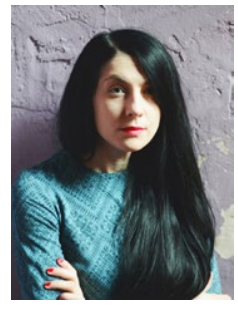

Małgorzata Lebda-born in 1985, Doctor of Humanities (specializing in theory of literature and audiovisual arts), academic teacher associated with the Institute of Information Sciences of the Pedagogical University in Krakow. Scientifically interested in visual arts, neuroesthetics, and information visualization. Poet (winner of the Gdynia Literary Prize for 2019 in the Poetry category). Ultramarathon runner. Lives in Krakow. 
